\title{
Margaret McCartney: Cash as a treatment for poverty
}

\author{
Margaret McCartney general practitioner, Glasgow
}

The House of Lords has scuppered the government's plans-for now. Tax credits are complicated. They are payments made to UK families who earn less than a threshold amount. The House of Commons recently voted to change this payment system. This would result in childless and non-disabled people who work more than 40 hours a week being better off. People in the same groups who work 30 hours a week will be worse off, as will people who have children and work 30 to 40 hours a week on the minimum wage. ${ }^{1}$ The greatest average losses would occur in households with earnings below the third income decile. ${ }^{2}$

The tragedy is that poverty kills. Age at death is associated with postcode. Less money makes life harder and shorter in many ways: less education, poorer working conditions, more stress. ${ }^{3}$ Instead of taking money away, what happens if you give poor people money? Halfway through an eight year study of children's mental illness, a casino opened in a Native American reservation in the United States. As a consequence, under the terms of the agreement, every Native American family received an income that rose annually. Before the casino the researchers found that the poorer the family, the greater the risk of mental distress. After paying the families, however, the rate of mental distress among children who had once been poor was about the same as in children who had never been poor. ${ }^{4}$ By the time those children were 25 , researchers still found persistent benefits in the group associated with the childhood cash injection. ${ }^{5}$

Tax credits mitigate in-work poverty. What about people who are homeless and out of work? A small project in London took 15 people who had been sleeping rough for four to 45 years. ${ }^{6}$ They were offered money-about $£ 800$ in the first year-and a personal coordinator, and they were asked what they needed. Thirteen accepted. The homeless person, rather than the coordinator, led the conversation and chose where to meet; promoting dignity seems to have been a fundamental part of the relationship. People spent the money on small bills, food, or educational courses. Seven moved into accommodation, and, although questions undoubtedly remain about the long term usefulness and potential harms, this work carries a strong message about the power of cash in a system flexible enough to be kind.
For some time, cardiovascular risk calculators such as ASSIGN have promoted postcode as a risk factor, which has meant literally that we are treating poverty with statins. Medicine cannot compensate for poor political choices. Here's a suggestion: why not treat health inequalities with the careful use of money?

Competing interests: I have read and understood the BMJ policy on declaration of interests and declare the following interests: I'm an NHS GP partner, with income partly dependent on Quality and Outcomes Framework points. I'm a part time undergraduate tutor at the University of Glasgow. I've written two books and earn from broadcast and written freelance journalism. I'm an unpaid patron of Healthwatch. I make a monthly donation to Keep Our NHS Public. I'm a member of Medact. I'm occasionally paid for time, travel, and accommodation to give talks or have locum fees paid to allow me to give talks but never for any drug or public relations company. I was elected to the national council of the Royal College of General Practitioners in 2013 and am chair of its standing group on overdiagnosis. I have invested a small amount of money in a social enterprise, Who Made Your Pants?

Provenance and peer review: Commissioned; not externally peer reviewed.

Follow Margaret on Twitter, @mgtmccartney

1 Ebell M. Taxes, tax credits and welfare spending National Institute of Economic and Social Research. May 2015. www.niesr.ac.uk/blog/taxes-tax-credits-and-welfare-spending\# Viypb9btg20.

2 Kennedy S, Keen R. Tax credit changes from April 2016. House of Commons Library briefing paper CBP7300. 15 Oct 2015.

3 Marmot M. The health gap: the challenge of an unequal world. Lancet Sep 2015, doi:10. 1016/S0140-6736(15)00150-6.

4 Costello E, Compton SN, Keeler G, Angold A. Relationships between poverty and psychopathology: a natural experiment. JAMA 2003;290:2023-9.

5 Akee R, Simeonova E, Costello EJ, Copeland W. How does household income affect child personality traits and behaviors? National Bureau of Economic Research working paper 21562. Sep 2015. www.nber.org/papers/w21562.pdf.

6 Joseph Rowntree Foundation. Providing personalised support to rough sleepers. 28 Oct 2010. www.jrf.org.uk/report/providing-personalised-support-rough-sleepers.

Cite this as: BMJ 2015;351:h5752

๑ BMJ Publishing Group Ltd 2015 